\section{Category}

Metal-Catalyzed

Asymmetric

Synthesis and

Stereoselective

Reactions

\section{Key words}

\section{Brønsted acids}

amines

reductive amination

iron
S. ZHOU, S. FLEISCHER, H. JIAO, K. JUNGE, M. BELLER* (LEIBNIZ-INSTITUT FÜR KATALYSE E.V. AN DER UNIVERSITÄT ROSTOCK, GERMANY AND CENTRAL CHINA NORMAL UNIVERSITY, WUHAN, P. R. OF CHINA)

Cooperative Catalysis with Iron and a Chiral Brønsted Acid for Asymmetric Reductive Amination of Ketones Adv. Synth. Catal. 2014, 356, 3451-3455.

\title{
Asymmetric Reductive Amination of Ketones
}
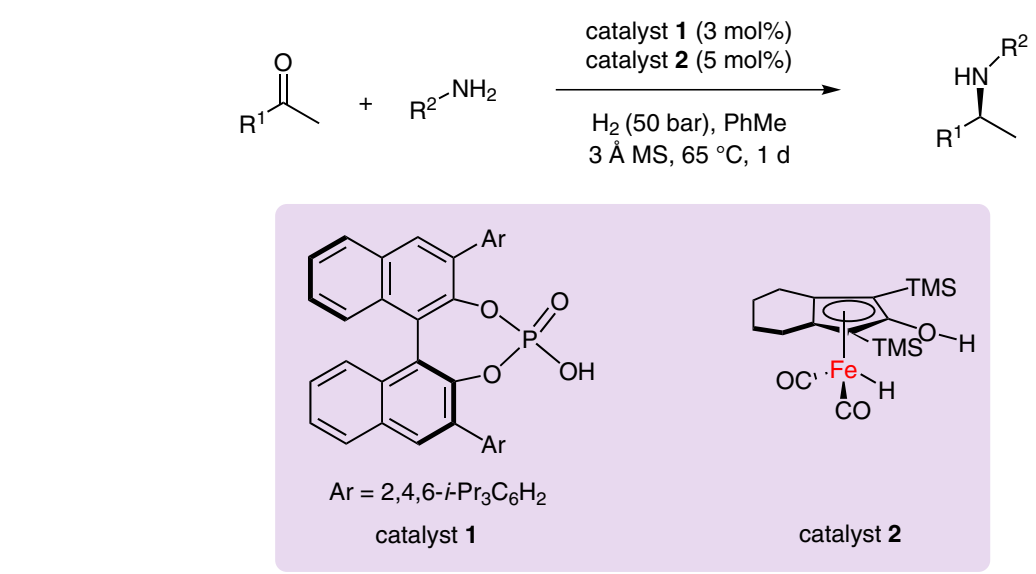

Selected examples:<smiles>COc1ccc(C(C)NPNC(=O)[O-])cc1</smiles>

$60 \%$ yield, $84 \%$ ee<smiles>Cc1ccc(NC(C)c2ccccc2)cc1</smiles>

$60 \%$ yield, $94 \%$ ee<smiles>CC(NP)c1ccccc1</smiles>

$64 \%$ yield, $94 \%$ ee<smiles>CCc1ccc(NC(C)c2ccccc2)cc1</smiles>

$68 \%$ yield, $93 \%$ ee<smiles>CCCCCCNC(=O)NC(C)c1ccc2ccccc2c1</smiles>

$70 \%$ yield, $94 \%$ ee<smiles>CC(Nc1ccc(C(C)(C)C)cc1)c1ccccc1</smiles>

$74 \%$ yield, $93 \%$ ee<smiles>CC(NP)c1cccs1</smiles>

$80 \%$ yield, $73 \%$ ee<smiles>CC(Nc1ccc2c(c1)OCO2)c1ccccc1</smiles>

$62 \%$ yield, $95 \%$ ee
Significance: Enantiomerically pure chiral amines are very important building blocks to synthesize numerous pharmaceutical drugs as well as bioactive compounds. The authors report the first ironcatalyzed asymmetric reductive amination of ketones with anilines in the presence of hydrogen, leading to chiral amines in moderate to good yields and good to excellent enantioselectivities.
Comment: The protocol represents a more convenient, simple and practical method for the synthesis of chiral amines. Interestingly, the combination of the chiral Brønsted acid (TRIP) catalyst and the non-chiral Knölker complex enabled the reductive amination of ketones with anilines in a cooperative manner. 